\title{
子宮内膜症に対する細径腹腔鏡下手術
}

大阪医科大学 産婦人科 ${ }^{1}$ 、北摂総合病院 産婦人科 ${ }^{2)}$ 永昜洋子 ${ }^{1)}$ 、奥田喜代司 ${ }^{1,2)}$ 、恒藤啓示 ${ }^{1)}$ 、中村嘉宏 ${ }^{2)}$ 、吉田陽子 ${ }^{1)}$ 、 林 篤史 ${ }^{1)}$ 、林 美佳 $^{1)}$ 、山下能毅 ${ }^{1)}$ 、寺井義人 ${ }^{1)}$ 、大道正英 ${ }^{1)}$

\section{Mini-Laparoscopic Surgery for Patients with Endometriosis}

Yoko Nagayasu ${ }^{1)}$, Kiyoji Okuda ${ }^{1,2)}$, Satoshi Tsunetoh ${ }^{1)}$, Yoshihiro Nakamura ${ }^{2)}$, Yoko Yoshida ${ }^{1)}$, Atsushi Hayashi ${ }^{1)}$, Mika Hayashi ${ }^{1)}$, Yoshiki Yamashita ${ }^{1)}$, Yoshito Terai ${ }^{11}$, Masahide Ohmichi ${ }^{1}$

Dept. of Obstetrics and Gynecology Osaka Medical College ${ }^{1)}$,

Dept of Obstetrics and Gynecology Hokusetsu General Hospital ${ }^{2}$

\begin{abstract}
Introduction: In an attempt to reduce pain and improve cosmetic outcome in laparoscopic surgery, there has been a recent drive to reduce port sizes (mini-laparoscopic surgery: MLS) or port number (single-site laparoscopic surgery). We evaluated the safety and efficacy of MLS in the patients with endometriosis and compared its outcome with that of the conventional laparoscopic surgery (CLS).

Methods: MLS was conducted with one 5-mm port for a 5-mm laparoscope as well as one 5-mm port and two 2.3-mm ports for the MiniLap Grasper. Conventional laparoscopic surgery (CLS) employs one 12-mm port for a 10-mm laparoscope and three 5-mm ports. A total of 24 patients with endometriomas underwent MLS (13) or CLS (11). We compared patient characteristics, operative findings, complications, postoperative pain medicine requirements, and serum CRP levels.

Results: The total r-ASRM (Revised American Society for Reproductive Medicine classification of endometriosis) scores for patients with endometriomas were not significantly different between the MLS (56.5) and the CLS (52.9) groups. Two of 13 patients were converted from MLS to CLS because of severe tubal adhesions. However, no major postoperative complications were encountered. Median operating times were similar between MLS (123 minutes) and CLS (107 minutes). The mean frequency of analgesic administration and serum CRP levels were significantly lower following MLS than following CLS (Mean frequency $1.5 \pm 0.53$ for MLS and 2.7 \pm 0.6 , CRP $0.66 \pm 0.28$ for MLS and $1.00 \pm 0.53$ for CLS). Cosmetic outcomes were superior with MLS, compared to CLS.

Conclusions: Compared to conventional laparoscopic surgery, the use of mini-laparoscopic techniques resulted in decreased incisional pain in the early postoperative period while improving cosmetic appearance.
\end{abstract}

Key words: MiniLap, mini-laparoscopic surgery, reduced port surgery, endometriosis

\section{【はじめに】}

腹腔鏡下手術は開腹手術に比べて低侵襲である ことより、機器の発達や手技の熟練により手術適 応を広げ、安全に、頻用されるようなってきた。 近年、より低侵襲や整容性の改善を目指しての reduced (number or size) port surgeryが脚光
を浴びており、この手術はポート数を減らす方法 (単孔式腹腔鏡下手術) と小さなポート径で行う 細径腹腔鏡下手術に分類できる。細径腹腔鏡下手 術は光学機器の発達により腹腔鏡の細径化 (2.0 〜 $3.0 \mathrm{~mm}$ 径) $)^{1,2)}$ が可能になり、検査を主体に報告 されている。この細径腹腔鏡と細径鉗子 ( $3 \mathrm{~mm}$ 径）を使った細径腹腔鏡下手術は外科領域では 
RCTで虫垂切除術 ${ }^{3)}$ や胆囊摘出術 ${ }^{4-6)}$ などでその 有用性が報告されている。一方、婦人科領域での 細径腹腔鏡下手術は比較的簡単な癒着剥離、卵巣 囊腫摘出 ${ }^{7-9)}$ などの報告があるが、重症子宮内膜 症を含めた症例に対する手術の報告はみられな い。今回、子宮内膜症に対してょり細径化が進ん だ2.3mm径のポートと把持鉗子が一体となった MiniLap Grasper ${ }^{\circledR}$ (日本ストライカー株式会社 から2011年 4 月より市販、製造所: Stryker Endoscopy, USA）を使用した細径腹腔鏡下手術 (細径法) を行い、従来の腹腔鏡下手術（従来法） と比較検討したので報告する。

\section{【対象および方法】}

MiniLap Grasper ${ }^{\circledR}$ が市販された2011年4月から 9 月の 6 月間に卵巣チョコレート霟胞を有する子 宮内膜症で妊孕能温存を希望した24例を対象とし た。細径化腹腔鏡下手術（細径法）は臍上部に open法で $5 \mathrm{~mm}$ 径のカメラ用ポートを設置し、臍
高の側腹部に $5 \mathrm{~mm}$ 径の鉗子用ポートと両側側腹 部に2.3mm径のMiniLapを挿入して行った。一方、 従来法の腹腔鏡下手術（従来法）は臍上部に open法で10mm径のカメラ用ポートを設置し、側 腹部に $5 \mathrm{~mm}$ 径の鉗子用ポートを 3 本挿入 (図 1 ) して行った。腹腔鏡下手術は全身麻酔下で行い、 カメラはVISERA 腹腔・胸腔ビデオスコープ OLYMPUS LTF TYPE VP (直径: $5.4 \mathrm{~mm}$ 、視 野角： $80^{\circ}$ 、観察深度 : 18-100mm) とOLYMPUS 腹腔鏡 $\mathrm{A} 4884 \mathrm{~A}$ （直径： $12 \mathrm{~mm}$ 、視野角 : $80^{\circ}$ 、 観察深度：20-100mm）を使用した。手術は異な る 3 施設で同一術者が行い、既往開腹手術例は対 象から除外した。症例の選別はMiniLapを使用で きない一施設や $5 \mathrm{~mm}$ 径のビデオスコープを使用 できなかった11例には従来法による腹腔鏡下手術 を行い、 $5 \mathrm{~mm}$ 径の細径腹腔鏡およびMiniLapが 使用できた13例では細径腹腔鏡下手術を試みた。 これら細径法と従来法との腹腔鏡下手術操作の難 易度、手術時間、出血量、術前後のCRP值、術後

図 1 従来法と細径化法におけるポートの位置と切開創の大きさ

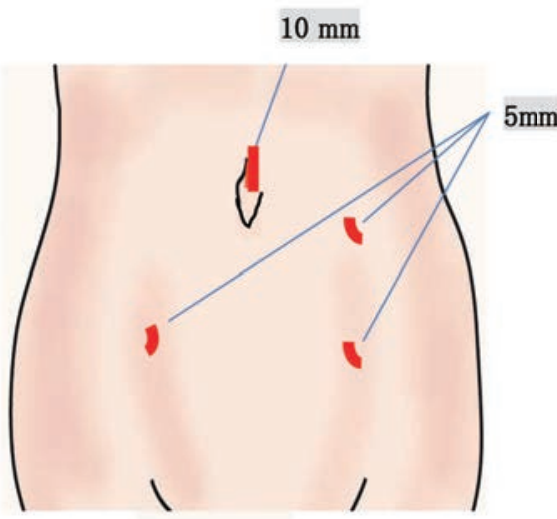

従来法: $10 \mathrm{~mm}$ のカメラポートと $5 \mathrm{~mm}$ の銝子ポート×3

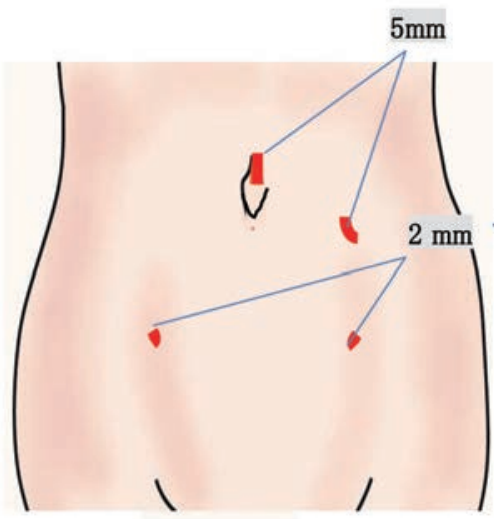

細径法: $5 \mathrm{~mm}$ のカメラポートと錐子ポート、 $2 \mathrm{~mm}$ の MinLap 銝子ポート× 2

図2 ポートと把持鉗子がー体となったMiniLap Grasper（有効長：27.5cm）

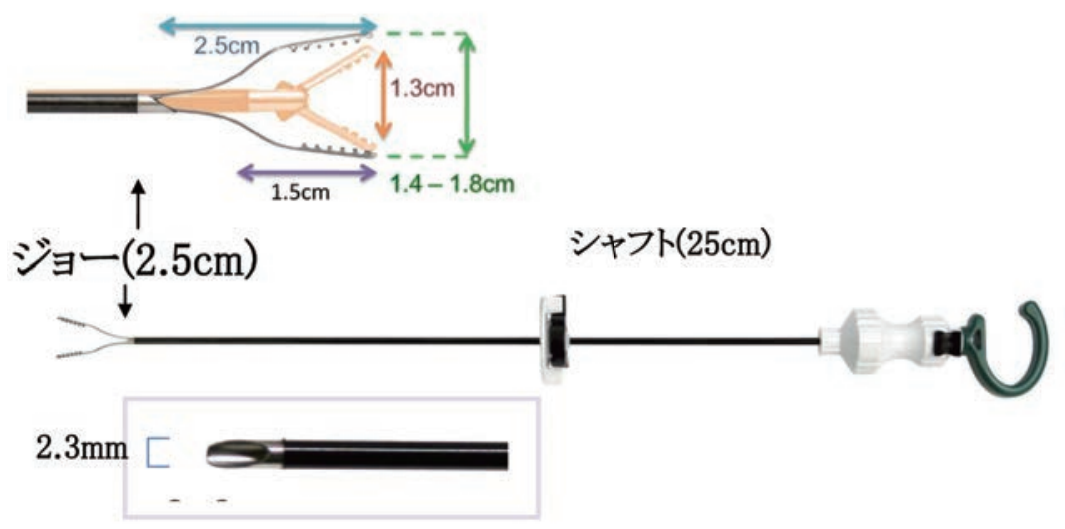


疼痛緩和剤の投与頻度や創部を比較検討した。

MiniLap Grasper ${ }^{\circledR}$ は2.3mm径のポートと把持 鉗子が一体となった（図2）デイスポーザブルの 器具である。先端の形状により 4 種類あるが、今 回の手術はアリゲーターとクラッチの 2 種類を使 用した。その構造をみると、シャフトの長さは $25 \mathrm{~cm}$ で、ハンドルを引くと把持する部分のジョ ーがシャフトの中に納まり、ハンドルを押すとジ ヨーが出てきて把持することができる。このジョ 一は細い $(2.3 \mathrm{~mm})$ が、 $25 \mathrm{~mm}$ と長く、把持する組 織面積が広いことから把持した組織を引き裂きに くい構造となっており、把持力も強い。MiniLap の腹腔内への挿入法は尖刃刀で皮虐を $2 \mathrm{~mm}$ 切開 し、MiniLapの先端をねじ达むように刺入する。 刺入後にハンドルのロックを解除してジョーをシ ヤフトより押し出して鋭いシャフトの先端で臟器 を損傷しないようにし、ピボットディスクの粘着 テープで皮膚にシャフトを固定する。

子宮内膜症に対する手術法 (図 3)：チョコレ 一ト襄胞（囊胞）（図 3 - (1) を有する子宮内膜 症では囊胞と広間膜とが癒着していることが多 く、MiniLapのジョーを開いて霊胞を圧排し、 5 $\mathrm{mm}$ 径の吸引管で癒着を鈍的に剥離する。この剥 離操作で囊胞が破綻することが多く、タール様内
容液を吸引管で吸引しながら、洗浄する。縮小し た囊胞を卵巣被膜とともにMiniLapで把持・杽引 し、広間膜との癒着剥離を鈍的に進め、剥離部か らの出血は $5 \mathrm{~mm}$ 径のバイポーラで止血する（同 時に剥離部の子宮内膜症病巣を焼灼)。同様に、 反対側の卵巣（囊胞）の広間膜との癒着を剥離す る。この側方の剥離が終わると、ダグラス窩の癒 着、すなわち、直腸と子宮の癒着部が明らかにな り、“一点展開法”10) で子宮と仙骨との癒着の一点 を鋏鉗子で切開し、子宮マニュプレーターと MiniLapで子宮を前屈しながら切開部より吸引管 で鈍的に剥離し（図 3 - (2)、剥離部をバイポー ラで焼灼する (硬結が残存する場合は切除)。最 後に、2本のMiniLapで破綻した襄胞と卵巣被膜 を把持して鋏鉗子で切開し、新鮮な創面を出す。 この創面に卵巣被膜と囊胞壁の境界部が明瞭に視 認できるため、その境界部に鋏銝子を挿入して剥 離する。剥離した囊胞壁と卵巣被膜を 2 本の MiniLapで把持し（図 3 - (3))、それぞれ反対方 向に牽引して震胞を卵巣被膜より剥離する。卵巣 被膜からの出血をバイポーラで止血し、摘出した 襄胞を袋（スリムバッグ ${ }^{\circledR}$ (八光商事K.K. $)$ ) に入 れてカメラポートより体外に摘出する。最後に(図 3 - (4)）側腹部の $5 \mathrm{~mm}$ のポートよりドレーン

図 3 細径化腹腔鏡下手術
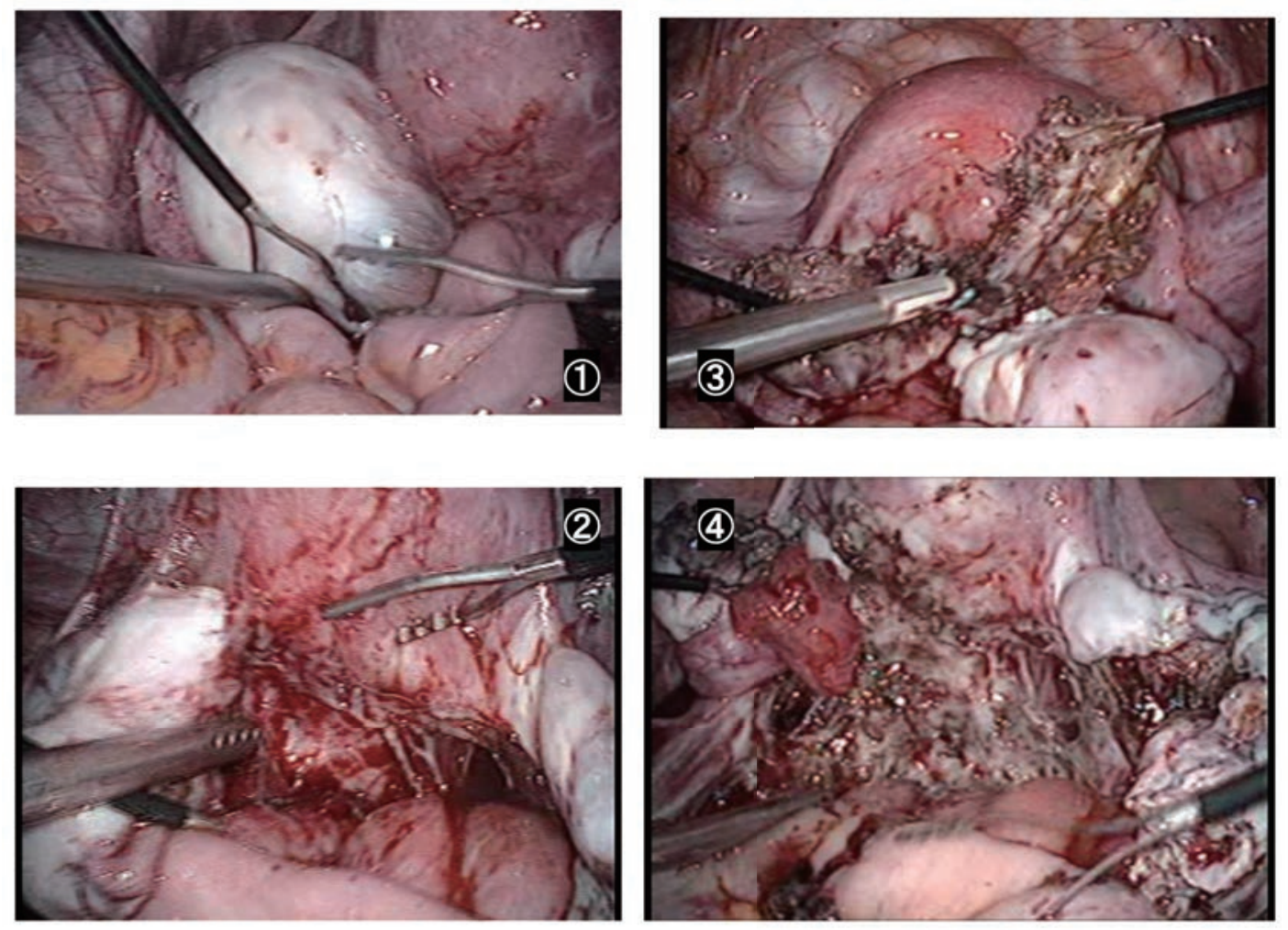

(1)両側チョコレート襄胞があり、ダグラス窩は完全に閉鎖 (3)囊胞摘除 (4)手術終了時

(2)囊胞周囲を剥離し、ダグラス窩を解放 
（15F）を挿入し、2本の操作用ポートおよびカ メラ様ポートを抜去して手術を終了する。

閉創方法は $5 \mathrm{~mm}$ スコープおよび10mmスコー プの挿入部はどちらも筋膜を 1 バイクリルで縫合 し、4-0PDSで真皮縫合をした。また、鉗子用 5 $\mathrm{mm}$ ポートの挿入部は4-0PDSで真皮縫合をし、 MiniLapの創部やその他の表皮はSteri-Stripテー プを貼付した。

\section{【結果】}

細径腹腔鏡下手術を子宮内膜症の 13 例に試みた が、 2 例ではMiniLapを $5 \mathrm{~mm}$ 径ポートに変更し て手術を終了した。これら 2 例中 1 例（35歳、 r-ASRMスコア：52）ではS状結腸が子宮および 付属器に癒着し、付属器が卵管を巻き込んで強固 に広間膜に癒着していた（図 4 - (1))。S状結腸 の癒着は剥離できた（図 4-(2)）が、卵管を把持 することができないためMiniLapで卵管を含む左 卵巣（囊胞）の圧迫剥離が困難であった。 MiniLapの 1 本を 5 mmポートに変更（図 4 - (3) して囊胞と広間膜の癒着を $5 \mathrm{~mm}$ 径の把持鉗子や 吸引管で鈍的に剥離した（図 4 - (4))。剥離後に
左卵巣囊胞摘出を行った。左卵管は $2 / 3$ 以上が癒 着していたために妊娠を期待できないと判定して 左卵管切除術を追加した。手術時間は235分と延 長したが、術後鎮痛郕使用回数は 1 回と少なく、 術後経過は順調であった。残りの 1 例（36歳、 r-ASRMスコア：68）でも右卵管が広間膜に強固 に 3 分の 2 以上が癒着し、卵管腫大がみられた。 MiniLap使用しての剥離が困難と判断し、 MiniLapの 2 本とも $5 \mathrm{~mm}$ 径ポートに変更して癒 着剥離、左チョコレート襄胞 $(4 \mathrm{~cm}$ 径) に対し て囊胞摘出、右チョコレート震胞 $(2 \mathrm{~cm}$ 径 $)$ に は襄胞内壁焼灼術を行った。癒着剥離した右卵管 は卵管留水腫であったため卵管摘出術を行った。 手術時間は125分で延長はみられず、術後鎮痛剤 の投与はなかった。これら症例を含む 24 例には大 きな合併症や開腹移行例はなかった。

従来法（11例）と細径法（11例）との年齢、 r-ASRM、囊胞径㧍よび手術時間の平均值 \pm 標準 偏差（表 1 ）を比較してみると、平均年齢はそれ ぞれ34.6歳と31.7歳で差がなく、r-ASRM分類の Total pointの平均值も52.9と56.5で差がなかった。 また、囊胞の平均径も $48.7 \mathrm{~mm}$ と $52.2 \mathrm{~mm}$ で差がな

図4 細径化腹腔鏡下手術より従来の腹腔鏡下手術に変更した症例
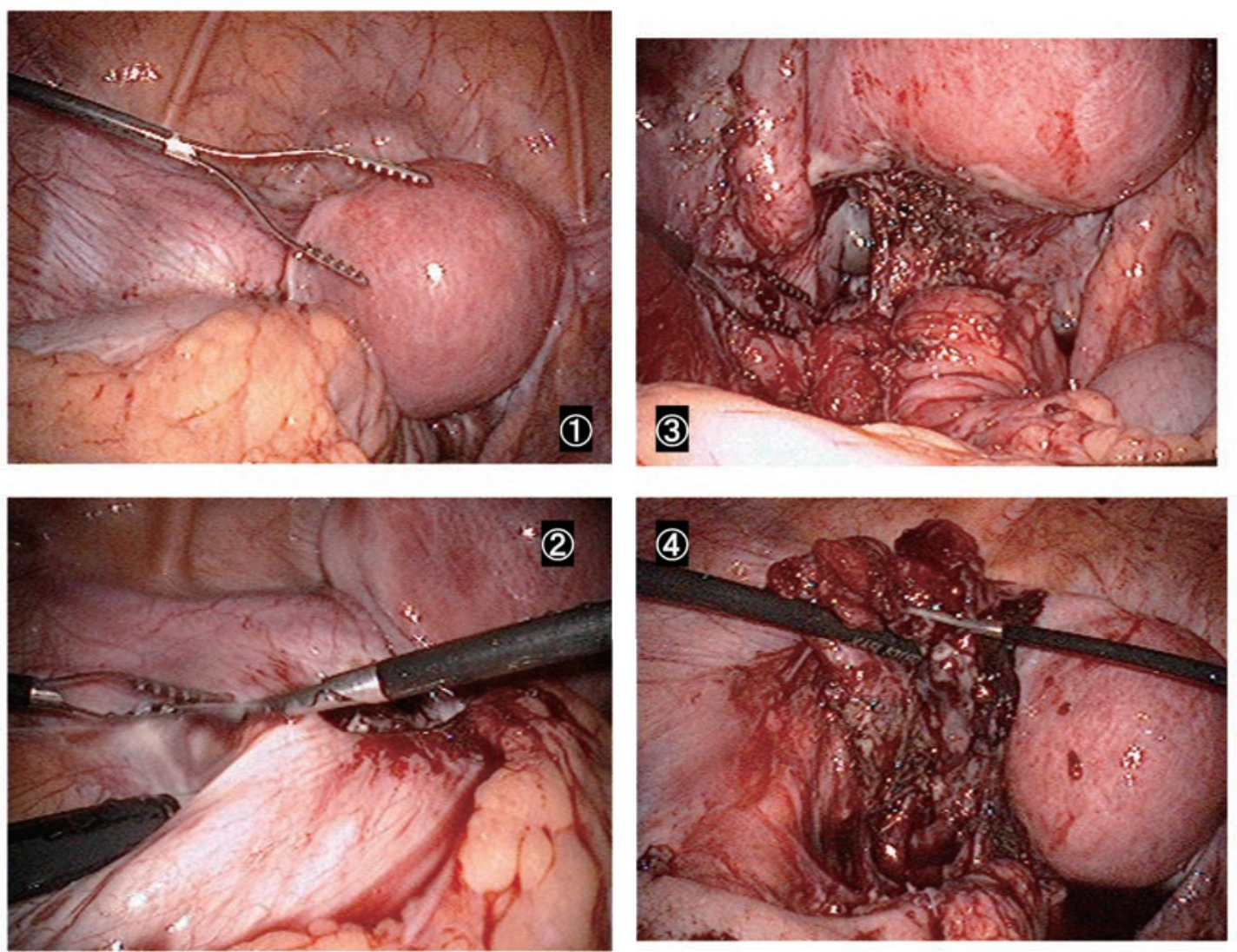

(1)左付属器に S 状結腸が強固に癒着 (2) S 状結腸の癒着を剥離

(3)チョコレート囊胞が卵管を巻き込んでいたため剥離困難なためMiniLapより5mmポートに変更 (4)付属器剥離を行ったところ 
表 1 従来法群と細径化群における年齢、r-ASRMスコア、囊胞径およ び手術時間の平均値士標準偏差

\begin{tabular}{|c|c|c|}
\hline & 従来法 ( $n=11)$ & 細径法 (n=11) \\
\hline 年齢(歳) & $34.6 \pm 7.3$ & $31.7 \pm 6.6$ \\
\hline r-ASRM 分類 (total point) & $52.9 \pm 17.6$ & $56.5 \pm 35.7$ \\
\hline 囊胞径 (長径) (mm) & $48.7 \pm 25.1$ & $52.2 \pm 24.5$ \\
\hline 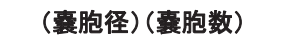 & $(25 \sim 120)(n=18)$ & $(30 \sim 125)(n=13)$ \\
\hline 手術時間(分) & $107 \pm 31$ & $123 \pm 33$ \\
\hline
\end{tabular}

かった。手術時間は従来法では107分で、細径化 群で123分とやや延長したが有意差はなかった。 また、術中の出血量はすべての症例で測定感度以 下（約 $50 \mathrm{ml}$ ）であった。手術後の鎮痛剂使用回 数（図 5 ) の合計は従来法で $2.7 \pm 0.6$ 回で、細径 化群では $1.5 \pm 1.1$ 回と有意 $(\mathrm{p}<0.01)$ に少なかった。 また、術後 1 日目の血中CRP值（図 6 ）は従来法 $(1.00 \pm 0.53)$ に比べて、細径化群 $(0.66 \pm 0.28)$ の方が有意 $(\mathrm{p}<0.05)$ に低值であった。術後の創 部をみると、MiniLap（外径 $2.3 \mathrm{~mm}$ ）挿入部の創

\section{図 5 従来法群と細径化群との術後鎮痛剂の使用回数}

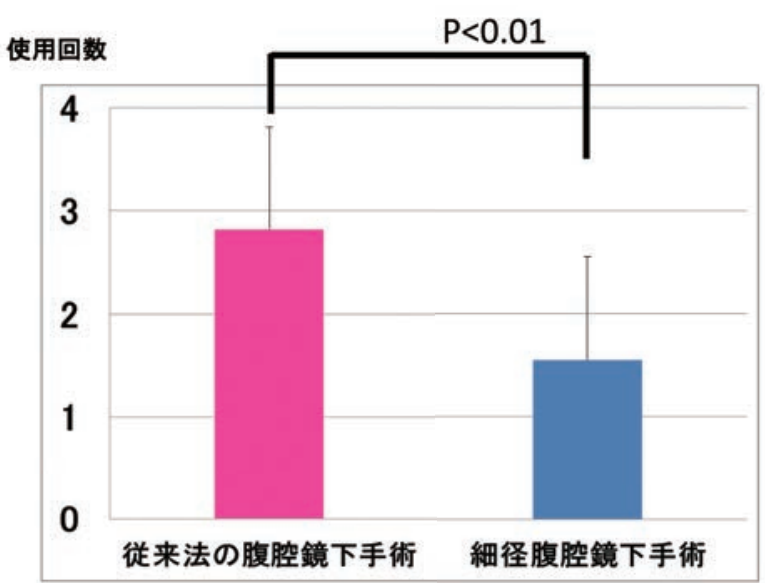

図 6 従来法と細径法との術後 1 日目の血中CRP値

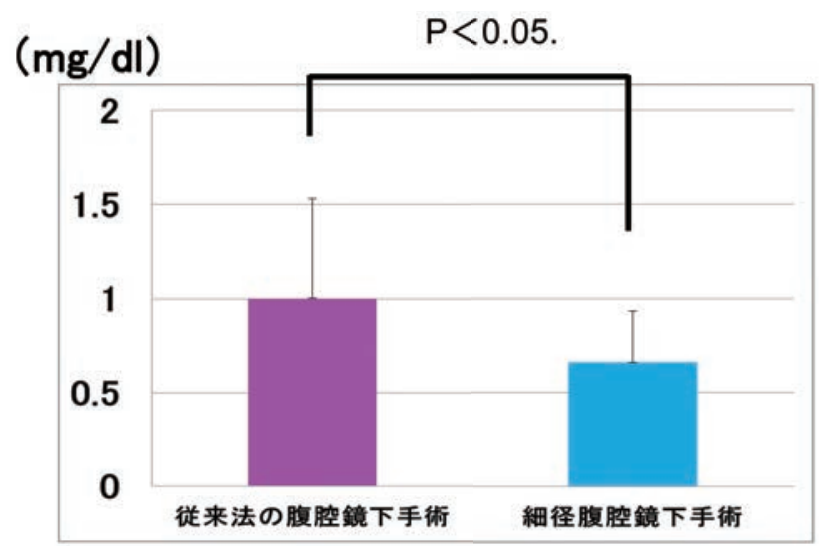

は $2 \mathrm{~mm} て ゙ 、 5 \mathrm{~mm}$ 径ポート（外径 $8 \mathrm{~mm}$ ）の創 （7-8mm）と比べて小さいので整容性に優れてい ると思われた。

\section{【考察】}

腹腔鏡下手術は開腹手術に比べて低侵襲（疼痛 の低減化、入院期間の短縮化、優れた整容性、早 期の回復）であることより、機器の発達や手技の 熟練により手術適応を広げ、安全に、頻用される ようなってきた。近年、より低侵襲や整容性の改 善を目指しての腹腔鏡下手術がreduced (number or size） port surgeryとして脚光を浴びており、 ポート数を減らす単孔式腹腔鏡下手術とポート径 を小さくする細径腹腔鏡下手術とがある。光学機 器の発達により腹腔鏡の細径化 $(2.0 \sim 3.0 \mathrm{~mm} \text { 径 })^{1.2)}$ が可能になり、検査を主体に報告されていた。腹 腔鏡の細径化と把持針子などの機器の細径 (3 $\mathrm{mm}$ 径）化を腹腔鏡下手術に応用した細径腹腔鏡 下手術は外科領域ではRCTで虫垂切除術 ${ }^{3)}$ や胆囊 摘出術 ${ }^{4-6)}$ などが検討され、その有用性が報告さ れている。一方、婦人科領域での細径腹腔鏡下手 術は比較的簡単な癒着剥離、卵巣囊腫摘出などの 報告 ${ }^{7-9)}$ があるが、重症子宮内膜症を含めた症例 に対する手術の報告はみられない。

今回、従来の細径銝子 ( $3 \mathrm{~mm}$ 径) より細径化 が進んだ $2.3 \mathrm{~mm}$ 径のポートと把持鉗子が一体とな ったMiniLap (Grasper $\left.{ }^{\circledR}\right)$ が市販されたことから 子宮内膜症患者を対象として細径腹腔鏡下手術 (細径法) を行い、同時期に行った従来法での腹 腔鏡下手術（従来法）の成績と比較検討した。従 来法の腹腔鏡下手術は $10 \mathrm{~mm}$ カメラポートの外径 は $13 \mathrm{~mm}$ で、 $5 \mathrm{~mm}$ 鉗子用ポート (外径 $8 \mathrm{~mm}$ ) が 3 本 (図 1 の左) で行い、細径化群の腹腔鏡下 手術は $5 \mathrm{~mm}$ カメラ用ポート (外径 $8 \mathrm{~mm}$ ) に変 更し、 2 本の $5 \mathrm{~mm}$ 鉗子用ポート (外径 $8 \mathrm{~mm}$ ) を2.3mm径のMiniLapに変更（図 1 の右）して行 った。細径腹腔鏡下手術を試みた 13 例中 11 例で手 術は細径針子のみで手術を終了したが、残り 2 例 では子宮内膜症の重症例（r-ASRMスコアが52 68）であり、卵管が卵巣を巻き込んで一塊となり 広間膜に強固に癒着していた。卵管の癒着剥離は MiniLapで卵管牽引できないため圧迫剥離を試み たが、MiniLapのシャフトが細いために困難であ った。MiniLap（1～2 本）を抜去し、 $2 \mathrm{~mm}$ の 切開創を $6 \sim 7 \mathrm{~mm}$ に延長して $5 \mathrm{~mm}$ ポート（外 径 $8 \mathrm{~mm}$ ）に変更した。 $5 \mathrm{~mm}$ 径の把持鉗子を挿 入し、卵管と囊胞を圧迫して広間膜との癒着を鈍 
的に剥離した。Mini Lapの特徴として径は細い が、ジョーが $25 \mathrm{~mm}$ と長く、従来の $5 \mathrm{~mm}$ の把持 鉗子と同等に組織の把持、牽引が可能で、霊胞摘 出は可能であった。一方、腸管、囊胞および子宮 の圧迫はMiniLapの径が細いため先端のジョーを 開いて行ったが、 $5 \mathrm{~mm}$ 径の鉗子に比べて 4〜 5 割位の圧迫のみしかできないと思われた。また、 使用したアリゲーターやクラッチによる卵管や腸 管の把持・毫引は組織損傷の可能性があり、 Bowel GrasperやBabcock Grasperが必要と思わ れたが、これらのMiniLapは用意できなかった。

従来法による腹腔鏡下手術群（従来法）と細径 腹腔鏡下手術群（細径法）との比較では、 r-ASRMスコアや襄胞径には差がなく、手術時間 にも有意差はなかった。しかし、手術時間は従来 法の対象となった症例の囊胞数が18個と細径群の 13個に比べて多いにかかわらず、従来法の方が細 径法に比べて平均手術時間が16分間短かった。こ の原因の一つに細径法では吸引注水管、バイポー ラ鈿子や鋏鉗子を唯一の $5 \mathrm{~mm}$ 鉗子用ポートより 出し入れするために手術時間が延長したとも考え られ、症例を重ねて検討する必要がある。一方、 術後疼痛緩和剂の投与頻度は細径群の方が従来群 より有意 $(\mathrm{p}<0.01)$ に少なく、術後1日目の血中 CRP值は従来法に比べて、細径群で有意 $(\mathrm{p}<0.05)$ に低值であった。これら結果は従来群と比べて細 径群ではより低侵襲であることを示している。山 中 $5^{8)}$ も同様に 22 例中 10 例が検査のみであるが、 鎮痛剂使用率、CRP陽性率㧍よび発熱で細径法が 従来法より侵襲度が有意に低いことを報告してい る。一方、今回の結果は従来法のカメラポート径 と鉗子ポート径の両方を細径化した結果であり、 MiniLap使用によって低侵襲化を眓れたとは言え ない。今後はカメラポート径を一定にして MiniLap使用群と非使用群と比べる必要がある。 同様に、術後の創部をみると、MiniLap（外径 $2.3 \mathrm{~mm}$ ）挿入部の創は約 $2 \mathrm{~mm}$ で、 $5 \mathrm{~mm}$ 径ポー 卜（外径 $8 \mathrm{~mm}$ ）の創（約7-8mm）と比べて小さ いので整容性に優れていると思われたが、客観的 な評価法を導入する必要がある。また、長期の整 容性を考え、術後の瘕痕期（数か月）にもマイク ロポアテープを貼付する自己管理を推奨してい る。外科領域では虫垂切除術 ${ }^{3)}$ や胆囊摘出術 ${ }^{4-6)}$ において細径化による腹腔鏡下手術は疼痛の低減 化や整容性などが優れていることがRCTで示さ れている。今回の子宮内膜症に対する細径腹腔鏡 下手術も同様の結果が得られたが、RCTや症例
を重ねて検討する必要がある。一方、整容的な観 点から臍部を切開 $(2 \sim 3 \mathrm{~cm})$ して腹腔鏡や鉗 子様ポートを扦入して行う単孔式腹腔鏡下手術が 報告されている。癒着が強い子宮内膜症に対して は単孔式では技術的に困難なこともあるが、細径 鉗子を一本追加することにより整容性もあまり損 なわれずに適応範囲を広げられる7) ことが報告さ れている。臍部の創は整容的な観点から優れてい ると考えられることから細径腹腔鏡下手術に応用 すれば、より整容的で、低侵襲な手術になるとも 考えられる。MiniLapはディスポ製品であるため コスト面から大きな出費（1本：2 万円）になる と考えられ、リユーズの細径把持針子の検討も必 要である。

今後は婦人科疾患の整容的および侵襲性の観点 からより細径の腹腔鏡やMini Lapなどによる細 径鉗子が再度脚光を浴びる可能性がある。

\section{文 献}

1 ) Sherwood R, et al. Minilaparoscopy for blunt abdominal trauma. Arch surg. 1980;115:672-673

2 ) 武内裕之他 婦人科領域における針状腹腔鏡の利用 日産婦内視鏡学会誌1996；12:126-131

$3)$ Mostafa G. et al. Mini-laparoscopic versus laparoscopic approach to appendectomy. BMC Surg. 2001; $1: 4$.

4 ) Huang MT, et al. Minilaparoscopic and laparoscopic cholecystectomy: a comparative study. Arch Surg. 2003; 138: 1017-1023.

5 ) Novitsky YW et al. Advantages of mini-laparoscopic vs conventional Laparoscopic cholecystectomy: results of a prospective randomized trial. Arch Surg. 2005; 140: 1178-1183

6 ) Gurusamy KS et al. Miniport versus standard ports for laparoscopic cholecystectomy. Cochrane Database Syst Rev. 2010; 17;(3):CD006804

7 ) 佐藤雄一 他 Day surgeryとしての細径腹腔鏡下 手術300例の検討 日産婦内視鏡学会誌 $2002 ； 18$ : 8385

8 ) 山中温子 他 当科における細径腹腔鏡システムの 検討 日産婦内視鏡学会誌1998；14: 83-86

9 ）望月修他 当科における細径腹腔鏡と従来式腹腔鏡 の比較検討 産婦人科治療1999. 79: 614-616

10）奥田喜代司 深部子宮内膜症に対する病態を考慮し た腹腔鏡下手術 エンドメトリオーシス研究会会誌 2004. 50: 78-83

11) Chong GO et al. Laparoendoscopic single-site surgery using a 2-mm miniport: initial gynecologic experience performed by a standard trocar and instruments. J Laparoendosc Adv Surg Tech A. 2010; 20: 605-608 